\section{Perception of Local Made products among young Tanzanians: Evidence from Mzumbe University Mbeya Campus}

\author{
Ansgar J. Sakaya (Corresponding Author) \\ Department of Business Studies Mzumbe University - Mbeya Campus \\ P.O. Box 6559 Mbeya-Tanzania \\ E-mail: ansgar.sakaya@gmail.com \\ Tel: +255683613636
}

$\begin{array}{lrr}\text { Received: February 5, } 2020 & \text { Accepted: February 19, } 2020 \quad \text { Published: March 28, } 2020 \\ \text { doi:10.5296/rbm.v7i2.16758 } & \text { URL: http://dx.doi.org/10.5296/rbm.v7i2.16758 }\end{array}$

\begin{abstract}
The study aimed at analyzing perception of local made products among young Tanzania consumers. Methodology used was a survey design. Data were collected through structured questionnaire. Stratified and simple random sampling strategies were used. The sample size was 200. Data were analyzed by use of factor analysis, multiple linear regression analysis, descriptive statistics, independent sample t-test as well as Pearson's correlation analysis.

It has been found that, students have shown low level of beliefs despite having good spirits on domestic products. Product quality and fashions are major problems of locally made products. No significant factors are used by University students in judging foreign products purchase. Age and Sex have failed to support the phenomena of ethnocentrism among University Students.

The study has recommended to marketers and local manufactures to modify their marketing mix specifically to product as quality was indicated to be a major problem for local products and improving local industries. Improvement in the areas of quality function deployment (QFD), Marketers should design adverts demonstrating the value of using home products for the purpose of changing people's attitude towards local made products, improvement of branding practices is also important. The government should rethink of reviving Technical schools, continue welcoming and encouraging foreign investors, investing in research and development also establishing online presence of locally made products and lastly is to practice a total or partial bun of those products imported often which are also produced in Tanzania.
\end{abstract}

Keywords: Consumer attitude; Ethnocentrism; CETSCALE; COO; Local products; Foreign Products; Tanzania 


\section{Macrothink 1 Institute}

\section{Motivation of the study}

The effects and the consequences of ethnocentric tendencies of Tanzania consumers have not been described in international research well and the main focus has been on West African sub region and has explored the effects of ethnocentrism in services marketing in the area of education (John \& Brady, 2009). Tanzania is not performing considerably in terms of production and trade, and to improve in these two aspects, it should first build the base of sustainable economic growth, by developing a market economy which would lead into creation of employment opportunities and economic transformation through private sector. Tanzania trade liberalization of 1990s aimed at increasing the inflow of goods across national borders and it was accelerated by increased population in the country and unavailability of product which caused high demand. It's from this time Tanzania started experiencing the increased influx of imported intermediary Goods. Hence, it can be said that, industrialization in Tanzania has been hindered by imports products which in turn, consumers see home product not favorably compared with those from highly developed countries (Ngasongwa, 2003).

Today's consumers have dilemmas in their purchase decisions, they may intend to buy domestic products to boost home industries but at the same time they are pleased with better featured and value of products from developed world which in turn changes their intention of buying local product and make them unpatriotic (Bandyopadhyay et al., 2011). Overseas businesses benefits countries through importation and exportation of goods which increases national income, employment opportunities for its people, and expansion of marketing and improve living standard of the people. However, a country may benefit more by exporting its strong home brands to other countries of the world. As such strong brand equity influences customers purchase intentions and increases revenues (Do Young Pyun et al., 2011).

There are domestic products produced in Tanzania such as, cooking oil, sugar, detergents, toothpastes, shoes, clothes, cosmetics and belts for men-ware but still, consumers' buy from outside the country. Brand's global image does influence consumer's decisions over local alternative brand even though its quality and value are not superior (Wei-Na Lee et al., 2003).

The main target of Tanzania government to participate in international trade was to increase income of the nation, employment opportunities, expansion of markets, improve living standard of the people and get unavailable requirement from other countries. According to Okechuku \& Onyemah, (1999), foreign products have brought a lot of difficulties in the operations of domestic industries in a number of countries. In Tanzania today, the importation rate is very high compared with goods produced within the country and it's very possible that, consumer now days consider imported goods first than domestic goods due to high availability of imports although this scenario in practice has been opposite of those customers from developed countries as Po-Young Chu et al., (2008) says, "Consumers from developed nations embrace much of their domestic products and even their nations do insist much on the buying and protection of home products that is why these customers have turned not to like product from third world countries. Teodoro et al., (1998); Okechuku \& Onyemah, (1999) argue that, customers who have high level of ethnocentrism have biased decision as they tend to judge domestic products favorably over the imported products. 


\section{Macrothink $\Lambda$ Institute ${ }^{\mathrm{m}}$}

Today our markets are loaded with import products from industrialized countries like China and other countries due to globalization. So, the presence of many overseas products in Tanzania markets which are similar to ours has motivated to study the feelings of people towards domestic and imported products. Sometimes consumers might have been influenced by good product features from certain country and yet do not make purchase because of the feelings of ethnocentrism as they believe such act may impair economic growth of their country (Selima et al., 2012).

\subsection{Aims of the study}

i. To study Tanzanians attitudes towards local made products

ii. To determine important factors used by customers in judging the purchase of foreign made product

iii. To measure consumer's ethnocentrism by using a modified CETSCALE

iv. To examine if age and sex influence the level of ethnocentrism among University Students in Tanzanian.

Hypothesis 1

$\mathrm{H}_{0}$ : Person's age has no influence on the level of ethnocentrism among Young Tanzanians.

$\mathrm{H}_{1}$ : Person's age influences the level of ethnocentrism among Young Tanzanian.

Hypothesis 2

Ho: Person's sex has no influence on the level of ethnocentrism among Young Tanzanians.

$\mathrm{H}_{1}$ : Person's sex influences the level of ethnocentrism among Young Tanzanians.

\subsection{Practical Implication}

This study is expected to add literature about Consumer Ethnocentrism in Tanzania. Also, this study is useful as the findings are expected to help marketers and local manufactures and policy makers to know the attitude of Tanzanians towards their local made products so that they can make strategic decisions as well as the base for understanding factors influencing consumers in buying foreign products instead of local products.

\subsection{Literature review}

Globalization of world market has given a way to a wider accessibility of products which has then raised the alarm on the risky associated with overseas products over domestic manufacture and employment (Kojo et al., 2010). To date, Many international business have relocated most of their production activities to emerging countries where the cost of operations are minimallow for the purpose of assisting their business enjoy cost advantages, and do away with potential risk of loss arising from harmful COO effects (Po-Young Chu et al., 2008). 


\section{Macrothink}

\subsection{Concept of Ethnocentrism inquire}

Soumava \& Munir, (2000) define ethnocentric consumers as those consumers who hold on the belief that, possessing products from overseas countries is going against your country. Hence ethnocentrism can be described as an incident that is deeply-rooted from liaison (group relationship) (Lewis, 1976, as cited by Habibur et al., 2010). Ethnocentrism in consumers can be manifested in areas of spiritual bias, community grouping, family unit discrimination, cultural prejudice, and patriotisms as well as nation's tribes and it has even been said that, ethnocentrism is an aspect of an individual life and does affect consumer attitude formation (Habibur et al., 2010). Thus, ethnocentrism is taken as a vital base for consumers in product evaluation process (Shimp \& Sharma, 1987). Tropp \& Pettigrew, (2005) says "Consumers who are ethnocentric always possess negative sentiment over overseas products; therefore, there is no need for them having the relationship with foreign product producers. Consumer's beliefs is more apparent in industrialized nations because of the accessibility and perceptual superiority over their domestic products as compared to consumers in emerging nation who sees overseas products as of better-quality compared to their own country's products (Wang \& Chen, 2004).

\subsection{Ethnocentrism and consumer attitudes}

Attitudes have an impact in the customer's final resolution towards product buying and attitude toward imports (Fazio et al., 1989). Ethnocentric Consumers may buy imported products due to their view of quality toward overseas products as well as if the need is considered very necessary due to unavailability of alternative in the local markets (Kojo et al., 2010). However, in other places, it has been very opposite as in the case of New Zealanders where they favors homemade product despite of the fact that, the imported substitute products were highly available at cheaper price and better quality (Watson \& Wright, 2000).

\subsection{CETSCALE}

CETSCALE is a tool that consists of 17 items which are in statement form and were much used in United State of America to measure ethnocentric tendencies (Shimp \& Sharma, 1987). Up to this moment, CETSCALE is used as a construct measurement for understanding the outcome of customer's feelings towards domestic and overseas products, thus the scale enlighten and gives answer as to why and to what extent consumers prefers locally made product as compared to foreign one. Hence, CETSCALE has been found to be a useful tool for measuring consumer's beliefs, attitude and purchase intention decisions (Shah Mohamed \& Ibrahim, 2012).

\subsection{Ethnocentric tendencies in relation to $\mathrm{COO}$ effect.}

Khan, (2009) believes that, "ethnocentrism is an antecedent to COO assessment". Where the product is made may have a negative or positive effect over customers' choice, this is called Country of origin effect (Watson and wright, 1999). Thus, COO is used as an elusive clue which involves name of the product, warranty and price that acts as a risk lessening; this is in contrast with tangible clues like design and flavor of the product. Consumer's evaluation of COO outcome under different products has a mixed and incongruous outcome (Kaynak \& Kara 
2002). Some studies have found factors like country's image and economic development stage to be a major determinant of product quality (Roth \& Romeo, 1992). Country of manufacturing has been found to be an imperative factor in determining consumer's feelings and buying judgment compared to brands value and features, other studies findings shows that, customers tends to embrace products whose COO have close relationship with their country in terms of commercial, social and diplomatic grounds (Klein et al., 1998).

\subsection{Demographic variables and Consumer Ethnocentrism}

Demographic factors have been found to have relation with ethnocentric tendencies and various research studies have addressed its effect on consumer purchasing intention, as it has been found from the literatures which says old people are more ethnocentric and have less passion with foreign made product due to their conservative nature as compared to youth (Bandyopadhyay \& Muhammad, 2000). Similarly, consumers who have good earnings and education have lower level of ethnocentrism as they are not stingy and they do not preserve old things (Anupam, 2004). Likewise, gender has been found to have impact in the level of ethnocentrism as, most of women have high level of ethnocentrism than men like in the case of Canada where women rated their home products much better than men, and it is said that, ethnocentrism is lack of knowledge, this can be evidenced by people who travel abroad as they are less ethnocentric due to fact that, they are exposed to foreign culture and broadening of minds (Balabanis et al., Nijssen, Douglas \& Bressers, 2002 as cited by Anupam, 2004).

\subsection{Methodology.}

A survey research design was used for data collection for describing a population that is big to study direct as well as obtaining information from a sample of people who answered a series of questions posed by a researcher; also the design gives an insight about the description of characteristics like aptitude, values, knowledge, view, beliefs and behavior of an individual, as well as situation or group (Polit \& Hungler, 1997). Quantitative approach was employed purposely to compute some data and examine the proportion of respondents opted for given answers, moreover, in quantitative approach results are controlled, firmly build and very objective (Polit \& Hungler, 1997; Burns \& Grove, 2001).

\subsection{Research settings}

The study took place at Mbeya City, one of the southern highlands regions of Tanzania. The study was confined to Mzumbe University students enrolled in undergraduate programs for the purpose of understanding their perceptual attitude towards foreign and domestic products. Studying their attitudinal behavior toward home made products was necessary because, Mbeya is bordered with several countries which produce almost same products as those produced in Tanzania and their products are highly available like Laundry soaps, Bath soaps Soft drinks, Kanga, detergents, toothpastes, sandals and belts for men-ware. Right, now the Government of Tanzania insists on purchasing of local products for the purpose of fostering industrialization which will in turn boost employment level. So it is better to study the attitudinal behavior of students customers with regards to Tanzania markets so as to know whether they consider home products useful as compared to foreign one or not. 


\section{Macrothink Institute ${ }^{\mathrm{m}}$}

\subsection{The study Population, sample size and sampling techniques}

Population is a set of items for focus of which the study intends to examine its characteristics (Turner, 2011). The targeted population comprised students enrolled in undergraduate programs who represented the general view of young consumers at Mbeya City. The population was identified and be studied because students is a group that can be termed as a growing important market that can manage to pay for luxurious imported products (Cox 1996; Saywell, 1997). Krishnaswami (2002) argues that, a sample is a small part that represents the big part of the population and is based on the assumption that, the elements of the population have similar characters and therefore, can represent the population. The sample was obtained by considering the Taro Yamane's formula with the confidence level of $93 \%$ and $7 \%$ was considered as the sampling error.

$\mathrm{n}=\mathrm{N} / 1+\mathrm{N}(\mathrm{e}) 2$ (Yamane, 1973).

$$
\begin{aligned}
& \text { Whereby } \quad \begin{array}{l}
\mathrm{n}=\text { Size of the Sample } \\
\mathrm{N}=\text { Size of population } \\
\mathrm{e}=\text { Precision level }(93 \% \text { confidence level or } 7 \% \text { precision level was assumed) } \\
\mathrm{n}=3280 / 1+3280(0.07)^{2} \\
\mathrm{n}=192.127 \approx 200 \text { (Rounded to nearest hundred). }
\end{array}
\end{aligned}
$$

Due to large population, the sample size was rounded to nearest hundred which is 200 in order to come up with more representative sample. Thus, the representative sample constituted of 200 respondents. The population under study was divided into two stratums, the first stratum was for those students enrolled in business studies and the second stratum was for students enrolled in Administrative Studies. Simple random strategy was employed for the purpose of allowing equality of representative items selection from each stratum also, these respondents might have differences of ideas towards locally made products, and moreover, this strategy helps minimize favoritism and simplifies analysis of results (Saunders et al., 2006). The sample size was then divided by the population and converted into percentage for the purpose of getting the representative sample size of each programme which is $6.09 \%$ found by $((200 / 3280) * 100)$ as seen in table 1.0 in appendix " $\mathrm{B}$ ".

\subsection{Types of Data and Collection Methods}

Secondary information was made from journals, books and research papers while primary information was attained by the use of survey questionnaires. Questionnaires are chain of preprinted questions which are sent to respondent and returned once solved (Kothari, 2004). For the case of this study, structured questionnaires were conveniently administered in English language because it is used as the medium of instruction in higher learning Institutions in Tanzania. The questionnaires constituted four parts, the introduction part was for personal information and the next part intended to identify consumer attitude towards the home made product, the other part intended to identify factors considered in purchasing decision and the last part was for CETSCALE to measure consumer ethnocentrism of Tanzanians as it was used to test Americans' ethnocentric tendencies (Shimp \& Sharma, 1987). The scale was used due 
to its reliability and validity and it has been validated in Central and Eastern Europe as well as in Africa (Kojo et al., 2010). The scale has 17 items but in this case the items in consideration were only 16 that sweated the Tanzania environment. Questionnaires were preferably on likert scale that bared 5 point. Students were demanded to point out the level of agreement to a number of statements telling about their perceptual attitudes. In total, 200 surveys questionnaire were circulated, thereafter, were all picked for processing.

\subsection{Analysis of data}

Descriptive statistics was used in analysis for the aim of describing the features of the study sample and it also involved frequencies and percentage. Factor analysis was applied to find out the interrelationships of the variables as well as explaining their common dimensions (Hair et al., 2006). Performing factor analysis was important as it helped in assessing internal reliability of the study measurement tool; also to reduce information from original variables into a lesser set of variables to minimize the possibility of information loss (Hair et al., 2006) The Cronbach's alpha value for the questionnaire is .749. Out of 200 respondents $28.6 \%$ were males and $26.9 \%$ were female. The aging structure of the population was composed with people of the age ranged from 18-23 which accounted for 23.1\%, 24-29 accounted for $22.5 \% 30-35$ accounted for $7.2 \%$, and $36-41$ accounted for $2.8 \%$ of the total population.

The study finding from table 1.1 in appendix "B" has shown that, $31.9 \%$ of respondent had a positive attitude while $18.3 \%$ had negative attitude towards the made in Tanzania. The study of Balabanis \& Diamantopoulos (2004) showed that, the negative intents on overseas products as equated to positive intents towards products made domestically are highly determined by consumer ethnocentrism. The study went farther and asked those who indicated to have negative attitude about Tanzania made product to indicate the reason for their attitude, answers are shown in table 1.2 in appendix "B". Argyrious and Melewar, 2011 says positive consumer attitude towards products often give a way to a good consumer buying decisions.

The study findings from table 1.2 in appendix " $\mathrm{B}$ " have shown quality problem, unfashionable, not of status and unreliability of local products to be the prominent reasons for their negative attitude in hand with other factors as seen in table which also accounted for the attitude.

It can be concluded that, factors used by University Students in this case in making judgment of buying foreign made products is highly not clear as all factors were not significant as it can be seen from table 1.3 in appendix "B". But, if the mean values are taken into consideration, males use Social status, and product safety for judgments while females use brand name, product price, social status and product safety for their judgments, although, these factors are not significant as seen from table 1.3, therefore, they are also not guaranteed under this case due to the nature of the respondents. It has been given that, all mean values less than 2.75 signify poor, while 2.75 to 3.25 signify normal, whereas 3.25 to 4.00 signify good as well as all the mean value higher than 4.00 will signify exceptional (Pikkemaat, 2004). Some authors have written about factors used by non-students in judging product purchases from other countries and pointed out about country of origin, social status, product quality, fashions familiarity and brand name as most of the factors used for judgments although, the results are contradictory sometimes (Klein et al., 1998; Batra et al., 2000; Samoui, 2009). 
Table 1.4 in appendix "B" shows standard deviation of the factors and the mean values that give a picture of consumer's ethnocentric tendency in Tanzania. Items with the mean value above 2.75 signify high consumer ethnocentric tendency and in this case University students as consumers under discussion have shown very low level of consumer ethnocentrism as it is only three items; number 4, 5 and 14 from the CETSCALE that indicate ethnocentric tendency of University Students as they have values higher than 2.75 as suggested (Pikkemaat, 2004).

Table 1.5 in appendix "B" expresses the correlation of the CETSCALE items undertaken to study ethnocentric tendencies of University Students in Tanzania and the findings have revealed that, a small number of variables are correlated at significance level of 0.05 while most of the variables correlations are statistically at 0.01 of significant level, this grant a good base for continuing using Factor Analysis as vindicated by Kaiser-Meyer-Olkin Measure of sampling adequacy results of .853 for the CETSCALE items, which indicates high adequacy of the sample for analyzing the factor as the significance level of Sphericity from the Bartlett's Test stands at 0.000 .

\section{Factor Analysis}

The CETSCALE variables were subjected to factor analysis for the purpose of measuring ethnocentric tendency by extracting factors loading below or less than 0.6. Some studies used same criterion and ended with positive answers (Isaga, 2012). Thus, the statistical value of KMO (Kaiser-Meyer-Olkin Measure of sampling Adequacy) was .853, which indicates high adequacy of the sample for the factor analysis. The significance level of Sphericity from the Bartlett's Test stands at 0.000

The records of factors found were four in total as in table 1.6 in appendix "B". Cumulative proportion of inconsistency explained by all four factors accounted for fifty seven percentages $(57.862 \%)$. Factor one alone describe $18.721 \%$ of the overall inconsistency. Factor two alone describe $16.785 \%$ of overall inconsistency, initially the two factors can describe $35.507 \% \%$ of the entire inconsistency. Factor three explains $14.516 \%$ of the entire inconsistency, so, all three factors describe $50.022 \%$ of the entire inconsistency. Factor four alone describes $7.839 \%$ of the entire inconsistency. Together, all four factors describe $57.862 \%$ of the entire inconsistency.

The rotated component matrix in table 1.7 in appendix " $\mathrm{B}$ " reveals how different individuals allied to diverse ethnocentric factors, in this case, it has shown a satisfactory internal consistence with the total Cronbach's Alpha of .861, and likewise, each factor's Cronbach's Alpha was .825, .792, .740, and .550 .

Thus, from table 1.7 in appendix " $\mathrm{B}$ " factor one involved item 5, 6, 7, 11, 14 and16. Factor two involved item 3, 7, 8, 9, 10, 11, 13 and 15. Factor three involved item number 1, 2, 3, 7 and 12. Factor four involved item number 3, 4 and 5.

Table 1.8 in appendix "B" shows that ethnocentrism has negative relationship with age and gender in this case.

In this case, table 1.9 in appendix " $\mathrm{B}$ " shows the model value .153 which signify there being a high variation common between the dependent and independent variables, this means consumers' ethnocentrism depends on age and gender by $1.53 \%(\mathrm{R})$ which is very small. The 


\section{Macrothink MInstitute}

result tells that, the correlation of age and sex with ethnocentric tendencies was not significant in this case. R Square value is .024 which elucidate that, dependent variables are changed by independent variables by $2.4 \%$. The Durbin Watson $\mathrm{d}$ for age and gender $=1.500$ which falls around the significant value of $1.5<\mathrm{d}<2.5$, for that reason the first order linear autocorrelation of the data is not assumed.

ANOVA test in table 1.10 in appendix " $\mathrm{B}$ " shows the $\mathrm{p}$ value for consumer's age and gender is 0.109 which is high as compared to 0.05 . This implies that, the null hypotheses are accepted and this explains that, the linear association of age and sex with ethnocentrism is not present.

The coefficient table 1.11 in appendix "B" provides facts of models parameters (Beta values) and significance of the values. The unstandardized Beta coefficient provides measures of input for each variable of the model. From appendix 13, hypothesis $\left(\mathrm{H}_{0}\right)$ one state that, Person's age has no influence on the level of ethnocentrism among Young Tanzanians in purchase of local products and this is shown by (Beta-value -0.117 ; $t$-value $-1.610 ; p>0.05$ ). Hence, in this case age does not have any relationship with ethnocentrism. Hypothesis $\left(\mathrm{H}_{0}\right)$ two state that, Person's sex has no influence on the level of ethnocentrism among Young Tanzanians, it is shown by (Beta-value .087; t-value 1.190; $\mathrm{p}>0.05$ ). Hence, in this case, sex does not have relationship with ethnocentrism. Therefore, the results tell that, all the null hypotheses are accepted as there is no linear association of age and sex with ethnocentrism tendencies. In view of the fact that, there are multiple independent variables in the analysis, the importance of each independent variable in standardized terms is assessed by Beta weights. It is found that, Test 1 and Test 2 have lesser impact as seen in the result (Test 1 beta $=-.117$ and Test 2 beta $=.87$ ). Under this case, The equation model is given as Ethnocentrism $=.000+-0.138$ (Age) +0.173 (Gender) $+\varepsilon$. multicollinearity problem was tested to examine the degree to which independent variables are associated with each other and the answer showed that, there is no multicollinearity of independent variables as the value tolerance 0.988 which is greater than 0.1 and VIF is 1.013 which is less than 10. The study of Makanyeza \& Du Toit (2017) also found a negative relationship between demographic characteristics and ethnocentrism.

\subsection{Conclusion}

The study has concluded that, University Students from Mzumbe Mbeya Campus have lower level of ethnocentrism as to large extent, respondents involved showed to agree with few statements of the CETSCALE about six of them, moreover, people have been found to have positive attitude towards the home product, although, having positive attitude does not guarantee that they will purchase local made product due to some reasons propounded by them about problems facing local products which are quality problem, have no status, un-fashionable and not reliable. These three factors were prominent compared to other factors used to gauge the reasons for negative attitude held by respondents. Klein et al., (1998) advocate that, consumers with strong beliefs of their home products will only buy products from overseas if they deem those product are priced low, have superior value and offer them with better feature and are of high-status, all these factors will make them see their purchases be meaningful otherwise they will not buy. The other factor that is important to be addressed is reliability of local products in terms of functionality and performance. It should be understood that, product reliability has prominent role in the relationships between consumers and firms, trust has been 
found to be one of the important criteria used by consumers in developing purchase intentions, and this justifies trust being a good determinant of consumer behavior (Pavlou and Gefen, 2004). The study also found no significant factors used by students when making judgments for buying foreign made products, but, if the mean values were to be taken into consideration, males use social status, and product safety for judgments while females use brand name, product price, social status and product safety for their judgments, although, these factors as seen they are not significant thus are not guaranteed for such judgments. In hand with that, person's age and sex have no any associations with ethnocentrism in this case as Anupam, (2004) found that, the phenomenon of consumer ethnocentrism could not be well explained by some of the demographic characteristics. Sharma et al., (1995) also wrote that, the expected association of age and ethnocentrism could not be established in previous studies like in Korea.

\subsection{Recommendations}

The government should rethink of reviving the Technical schools as well as empowering VETA to prepare technical people for creating and innovating new things that will align with the current agenda of industrializing in Tanzania rather than having only many people who are graduate in administrative areas and cannot do the technical tasks related to industrial aspects.

The government should see the importance of continuing welcoming and encouraging foreign investors through proper regulations and conducive business environment that will guide their business conducts to have the production process in Tanzania of those product imported to Tanzania so that the country can benefit more and consumer can turn their minds towards local made.

Also the issue of product quality should be well emphasized by SIDO to local manufactures by conducting seminars in different parts of the country from time to time, inspire and subsidize the private efforts intended at improving the quality of domestic products that reflect our cultural values and attribute by taking an extra effort of helping them in areas of quality function deployment (QFD), lean principles and sensitizing about proper management practices as most of time, local products are taken to the market place with poor quality, poor workmanship creativity and poor innovative features which adversely impact buyer feelings on domestic products. Improvement of quality is supposed to be in all aspects like color, packaging, size, taste, furnishing, reliability, durability and good brand names.

Improvement of production technology is also important as the world has moved a lot and customers are well bombarded with products from various parts of the world which manifest technological curiosity of their production process which in turn attract customers to prefer foreign products instead of the local made.

The Ministry of industry and trade needs to have a model that will enable Tanzanian small firm's products and entrepreneurs to be locally competitive and export a diversified range of those products which are valued more in the international market so as to influence local and foreign buyers to embrace and build good attitude towards our locally made products.

Promoting globalization of locally owned small Tanzania firm's products through research and 


\section{Macrothink $\Lambda$ Institute}

development as a way to stimulate marketers and local manufactures to see the importance of studying well about factors influencing local consumers in buying foreign products, and find ways to improve so that local consumers can turn their minds to local products.

Marketers and entrepreneurs needs also to improve by modifying their marketing mix as they are important variables as it was mentioned from the study findings that, most of local products are priced higher than foreign products, and it should be remembered that: - Price is a determinant of sales revenue, Price is the determinant of demand, Price is a promotional tool, and Price is a competitive tool.

Establishing online presence of locally made products by promoting Online-Marketing through trainings as many small Tanzania firms are unable to use latest tools of IT due to lack of knowledge and high costs and a good number of people do not spend much time to do physical shopping rather they have turned their attention to the use of internet nowadays like social networking sight.

Policy makers and the government of Tanzania should insist in developing vigorous manufacturing industry that will revolutionize the attitudes of Tanzanians towards domestic products and examining the ways consumer in different parts of the country think about and use products before planning marketing programs. This will stimulate internal and external demand of our local products and lead to employment of most of the young Tanzanians who are graduate and non-graduate with no jobs which finally will lead to multiplier effects in the country.

The government needs also to take strong measure of no hesitant in total bun of those products imported often which are also produced in Tanzania unless if there are huge gains to the government from the business, at one time a country may impose some obstruction in its boundaries for the sake of protecting its infant industry as what is happening in steel industry India where they have a total bun for imported steel to protect their industries.

\section{References}

Argyriou, E., \& Melewar, T. C. (2011). Consumer attitudes revisited: A review of attitude theory in marketing research', International Journal of Management Reviews, 13(1), 431-451. https://doi.org/10.1111/j.1468-2370.2011.00299.x

Bandyopadhyay, S., \& Muhammad, M. (2010). Consumer Ethnocentrism in South Asia. IMS Manthan, 5(1).

Bandyopadhyay, S., and Muhammad, M. (2011). Consumer ethnocentrism in South Asia, Lamal University.

Batra, R., Venkatram, R., Alden, D. L., Steenkamp, J. E. M., \& Ramachander, S. (2000). Effects of brand local and nonlocal origin on consumer attitudes in developing countries. Journal of International Business Studies, 31(1), 157-175. 


\section{Macrothink AInstitutem"}

Bawa, A. (2004). Consumer ethnocentrism: CETSCALE validation and measurement of extent. Vikalpa, 29(3), 43-58.

Chu, P. Y., Chang, C. C., Chen, C. Y., \& Wang, T. Y. (2010). Countering negative country-oforigin effects. European Journal of Marketing, 44(7/8), 1055-1076.

Cox, K. (1996). Corporate India introduces the ol'compensation ploy. World Business, 2(6), 7.

Fazio, R. H., Powell, M. C., \& Williams, C. J. (1989). The role of attitude accessibility in the attitude-to-behavior process. Journal of consumer research, 16(3), 280-288.

Hair, J. F., Black, W. C., Babin, B. J., \& Tatham, R. L. (2006). Multivariate Data Analysis. New Jersey: Prentice Hall.

Isaga, N. (2012). Entrepreneurship and the growth of SMEs in the furniture industry in Tanzania (Doctoral dissertation, Amsterdam: Vrije Universiteit).

John, A. V. S., \& Brady, M. P. (2009). The Impact of Consumer Ethnocentrism Tendencies on Buyers Evaluation of the Quality of South African Packaged and Non-Packaged Consumables in Mozambique. International Journal of Business Research, International Academy of Business and Economics, 9(3) May.

Kaynak, E., \& Kara, A. (2002). Consumer perceptions of foreign products. European Journal of Marketing, 36(7-8).

Khan, I. (2012). Effect of consumer ethnocentrism and country-of-origin image: An overview of Bangladeshi consumers' perception towards foreign banks. Available at SSRN 2120377.

Klein, J. G., Ettenson, R., \& Morris, M. (1998). The animosity model of foreign product purchase: An empirical test in the People's Republic of China. Journal of Marketing, 62(1), 89-100.

Kojo, S., John, H. W., and Marica, M. (2010). The role of consumer ethnocentrism in a buy national Campaign in a transitioning country some evidence from Slovakia. International Journal of Emerging Markets, 2, 203-226.

Kothari, C. R. (2004). Research Methodology Methods and Techniques (2 ${ }^{\text {nd }}$ ed.). New Delhi, New Age International.

Krishnaswami, O. R. (2002). Methodology of research in social science: Himalaya publishing House- Mumbai 1st Ed.

Kwon, H. H., \& Lee, C. W. (2011). The influences of perceived brand quality and ethnocentrism on consumption patterns of a global sports brand: The case of Korean college students. International Journal of Sports Marketing \& Sponsorship, 13(1).

Kwon, H. H., \& Lee, C. W. (2011). The influences of perceived brand quality and ethnocentrism on consumption patterns of a global sports brand: The case of Korean college students. International Journal of Sports Marketing \& Sponsorship, 13(1).

Lee, W. N., Hong, J. Y., \& Lee, S. J. (2003). Communicating with American consumers in the 


\section{Macrothink AInstitutem}

post 9/11 climate: An empirical investigation of consumer ethnocentrism in the United States. International Journal of Advertising, 22(4), 487-510.

Lewis, R., Rowland, R., \& Clem, R. (1976). Nationality and population change in Russia and the USSR. An Evaluation of Census Data, 1897-1970. New York: Praeger, 149.

Makanyeza, C., \& Du Toit, F. (2017). 'Consumer ethnocentrism in developing countries: Application of a model in Zimbabwe' Acta Commercii, 17(1),

Mrad, S. B., Sheng, S. Y., \& Hart, L. K. (2013). Do rumblings lead to real action? A case of animosity and boycott in China. International Journal of China Marketing, 3(2), 35-48.

Ngasongwa (MP.), J. (2003). Minister for Industry and Trade, at the inauguration [sic] of NIDA Textile Mills (T) Ltd. by H.E. Benjamin William Mkapa, President of the United Republic of Tanzania, Dar es Salaam, 24th 2003 https://books.google.co.tz/books/about/speech_by_Hon_Dr_Juma_Ngaswongwa_MP_Minis. $\underline{\mathrm{html} ? \mathrm{~d}=\mathrm{mWy} 2 \mathrm{AAAAIAAJ} \& \mathrm{redir} \text { esc }=\mathrm{y}}$

Okechuku, C., \& Onyemah, V. (1999). Nigerian consumer attitudes toward foreign and domestic products. Journal of international business studies, 30(3), 611-622.

Pavlou, P. A., and Gefen, D. (2004), "Building Effective Online Marketplaces with InstitutionBased Trust". Information Systems Research, 15(1), 37-59.

Pikkemaat, B. (2004). The measurement of destination image: the case of Austria. The University of Innsbruck, 4(1), 87-102.

Rahman, H. M., Morshed, M., \& Hossan, M. T. (2011). Identifying and measuring consumer ethnocentric tendencies in Bangladesh. World Review of Business Research, 1(1), 71-89.

Roth, M. S., \& Romeo, J. B. (1992). Matching product catgeory and country image perceptions: A framework for managing country-of-origin effects. Journal of international business studies, 23(3), 477-497.

Samoui, F. (2009). Effet de l'origine perc, ue du nom de marque sur les perceptions duconsommateur: cas du consommateur de pays émergents. In 8th internationalcongress marketing trends (p. 27).

Saywell, T. (1997). Good Hunting Ground. Far Eastern Economic Review, 160(35), 57.

Shah, K. A. M., \& Ibrahim, H. I. (2012). Consumer ethnocentrism: does it really matter for Malaysian consumers. West East Journal of Social Sciences, 1(1), 26-38.

Sharma, S. H., Shimp, T. A., \& Shin, J. (1995). Consumer ethnocentrism: a test of antecedents and moderators. Journal of the Academy of Marketing Science, 23(1), 26-37.

Shimp, T. A., \& Sharma, S. (1987). Consumer Ethnocentrism: Construction and Validation of the CETSCALE. Journal of Marketing Research, 24(3), 280-289

Teodoro, L., JoseÂ-Angel, I., and Salvador del Barrio, G. (1998). Consumer ethnocentrism measurement. An assessment of the reliability and validity of the CETSCALE in Spain. 


\section{Macrothink

European Journal of Marketing, 34(11/12), 1353-1373.

Thornhill, A., Saunders, M., \& Lewis, P. (2009). Research methods for business students. Prentice Hall: London.

Tropp, L. R., \& Pettigrew, T. F. (2005). Relationships between intergroup contact and prejudice among minority and majority status groups. Psychological Science, 16, 951-957. http://dx.doi.org/10.1111/j.1467-9280.2005.01643.x

Turner, B. (2011). The Sociology of Religion.The SAGE handbook of Sociology, SAGE Publications, New Delhi, 301pp.

Wang, C. L., and Chen, Z. X. (2004). Consumer ethnocentrism and willingness to buy domestic products in a developing country setting: testing moderating effects. Journal of Consumer Marketing, 21(6), 391-400.

Watson, J. J., and Wright, K. (2000). Consumer ethnocentrism and attitudes toward domestic and foreign products. European Journal of Marketing, 34(9/10), 1149-66.

Yamane, T. (1973). Statistics and Introduction Analysis. $3^{\text {rd }}$ E. New York: Harper \& Row. 


\section{Macrothink $\triangle$ Institute ${ }^{\text {tm }}$}

\section{Appendices}

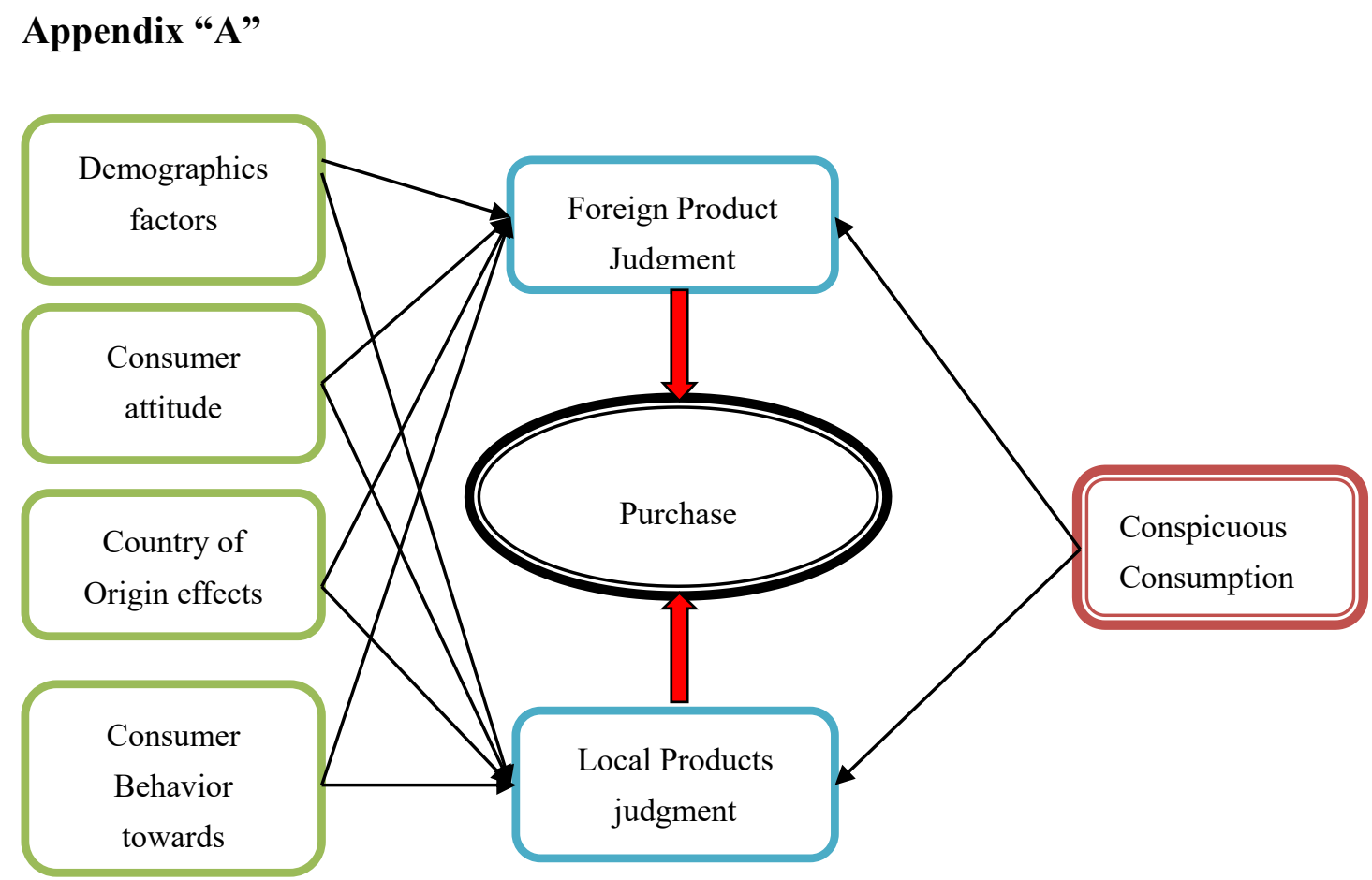

Figure 1.0 Suggested Conceptual Framework

\section{Appendix "B"}

Table 1.0 Distribution of Population and Sample size calculation

\begin{tabular}{|c|c|c|c|c|}
\hline Categories & Respondents & $\begin{array}{c}\mathbf{6 . 0 9 \%} \text { of } \\
\text { respondents }\end{array}$ & $\begin{array}{c}\text { Adjusted } \\
\text { Sample Size }\end{array}$ & $\begin{array}{c}\text { Sampling } \\
\text { Strategy }\end{array}$ \\
\hline Business Studies & 913 & 55.60 & 56 & $\begin{array}{c}\text { Random } \\
\text { Sampling }\end{array}$ \\
\hline $\begin{array}{c}\text { Administrative } \\
\text { Studies }\end{array}$ & 2,367 & 144.15 & 144 & $\begin{array}{c}\text { Random } \\
\text { Sampling }\end{array}$ \\
\hline Total & 3,280 & 197.13 & 200 & \\
\hline
\end{tabular}


Table 1.1 Tanzanians attitude towards local made products

\begin{tabular}{|l|l|r|r|}
\hline \multicolumn{2}{|c|}{ Attitude } & Frequency & Percent \\
\hline Valid & Positive & 115 & 31.9 \\
\cline { 2 - 4 } & Negative & 66 & 18.3 \\
\cline { 2 - 4 } & 3 & 9 & 2.5 \\
\cline { 2 - 4 } & 4 & 5 & 1.4 \\
\cline { 2 - 4 } & 5 & 4 & 1.1 \\
\cline { 2 - 4 } & Total & 199 & 55.3 \\
\hline Missing & System & 161 & 44.7 \\
\hline Total & & 360 & 100.0 \\
\hline
\end{tabular}

Table 1.2 Reasons for negative attitude towards local products

\begin{tabular}{|c|c|c|c|}
\hline & Frequency & Percent \\
\hline \multirow[t]{8}{*}{ Valid } & Quality & 60 & 16.7 \\
\hline & Unfashionable & 25 & 6.9 \\
\hline & Unavailable & 16 & 4.4 \\
\hline & Price & 17 & 4.7 \\
\hline & No-status & 24 & 6.7 \\
\hline & Not reliable & 18 & 5.0 \\
\hline & Others & 5 & 1.4 \\
\hline & Total & 165 & 45.8 \\
\hline Missing & System & 195 & 54.2 \\
\hline \multicolumn{2}{|l|}{ Total } & 360 & 100.0 \\
\hline
\end{tabular}




\section{Macrothink $\Lambda$ Institute "'}

Table 1.3 Important factors used by University Students Customers in judging the purchase of Foreign made Product in this case

\begin{tabular}{|c|c|c|c|c|c|c|}
\hline \multirow{2}{*}{ Variables } & \multirow{2}{*}{$\mathbf{N}$} & \multicolumn{2}{|c|}{ Mean \pm Std. Deviation } & \multirow{2}{*}{ t-Value } & Sig. (2-tailed) & \multirow{2}{*}{ Sign. } \\
\cline { 3 - 4 } & & Male & Female & & & \\
\hline Brand Name & 198 & $2.52 \pm 1.225$ & $2.79 \pm 1.239$ & 1.553 & .122 & NS \\
\hline Product Price & 200 & $2.61 \pm 1.470$ & $2.95 \pm 1.439$ & 1.636 & .103 & NS \\
\hline Country of Origin & 200 & $1.88 \pm 1.105$ & $2.06 \pm 1.171$ & 1.108 & .296 & NS \\
\hline Social Status & 200 & $2.96 \pm 1.475$ & $3.24 \pm 1.413$ & 1.350 & .179 & NS \\
\hline Product Familiarity & 200 & $2.06 \pm 1.327$ & $1.93 \pm 1.063$ & -.764 & .446 & NS \\
\hline Product Quality & 199 & $2.40 \pm 1.276$ & $2.41 \pm 1.265$ & .058 & .954 & NS \\
\hline Product Safety & 200 & $3.28 \pm 1.543$ & $3.39 \pm 1.578$ & 0.499 & .618 & NS \\
\hline
\end{tabular}

Note: NS=Non-Significant. $* * *=$ Significant at $\mathrm{P}<0.001$ and $* *=$ Significant at $\mathrm{P}<0.01$ 
Table 1.4 Descriptive statistics for Consumer's ethnocentric tendency from the CETSCALE items

\begin{tabular}{|c|c|c|c|c|c|}
\hline \multicolumn{6}{|c|}{ Descriptive Statistics } \\
\hline CETSCALE ITEMS & $\mathbf{N}$ & Minimum & Maximum & Mean & $\begin{array}{c}\text { Std. } \\
\text { Deviation }\end{array}$ \\
\hline $\begin{array}{l}\text { 1. Every time buy Tanzania } \\
\text { goods as an alternative of } \\
\text { imported goods }\end{array}$ & 200 & 1 & 5 & 2.14 & 1.213 \\
\hline $\begin{array}{l}\text { 2. Only unavailable products } \\
\text { in Tanzania should be } \\
\text { imported }\end{array}$ & 198 & 1 & 5 & 2.18 & 1.321 \\
\hline $\begin{array}{l}\text { 3. Buy Tanzanian products } \\
\text { keep Tanzania working }\end{array}$ & 199 & 1 & 5 & 1.75 & .953 \\
\hline $\begin{array}{l}\text { 4. Tanzanian products first } \\
\text { last and foremost }\end{array}$ & 200 & 1 & 5 & 2.78 & 1.360 \\
\hline $\begin{array}{l}\text { 5. Purchasing foreign made } \\
\text { products is untanzanian }\end{array}$ & 196 & 1 & 6 & 3.01 & 1.455 \\
\hline $\begin{array}{l}\text { 6. Purchasing foreign } \\
\text { products puts Tanzanians } \\
\text { out of jobs }\end{array}$ & 200 & 1 & 5 & 2.73 & 1.325 \\
\hline $\begin{array}{l}\text { 7. A real Tanzanian should } \\
\text { always buy Tanzanian } \\
\text { made products }\end{array}$ & 200 & 1 & 5 & 2.43 & 1.304 \\
\hline $\begin{array}{l}\text { 8. Buy our own products to } \\
\text { avoid countries from } \\
\text { getting rich off us }\end{array}$ & 199 & 1 & 11 & 2.02 & 1.293 \\
\hline $\begin{array}{l}\text { 9. All the time, buy } \\
\text { Tanzanian made products }\end{array}$ & 200 & 1 & 5 & 1.86 & 1.051 \\
\hline $\begin{array}{l}\text { 10. Trade of goods should be } \\
\text { very little unless out of } \\
\text { necessity }\end{array}$ & 199 & 1 & 5 & 2.06 & 1.181 \\
\hline $\begin{array}{l}\text { 11. Foreign products hurts our } \\
\text { businesses and cause } \\
\text { unemployment }\end{array}$ & 200 & 1 & 5 & 2.60 & 1.324 \\
\hline $\begin{array}{l}\text { 12. Curbs should be put on all } \\
\text { imports }\end{array}$ & 200 & 1 & 5 & 2.20 & 1.316 \\
\hline
\end{tabular}




\section{Macrothink}

Research in Business and Management ISSN 2330-8362

\begin{tabular}{|c|c|c|c|c|c|}
\hline $\begin{array}{c}\text { 13. In long run, it may cost } \\
\text { me but I favor Tanzanian } \\
\text { products }\end{array}$ & 200 & 1 & 5 & 2.10 & 1.169 \\
\hline $\begin{array}{c}\text { 14. Foreigners products } \\
\text { should not be allowed in } \\
\text { our markets }\end{array}$ & 199 & 1 & 5 & $\mathbf{3 . 4 7}$ & 1.421 \\
\hline $\begin{array}{c}\text { 15. Heavy taxation will } \\
\text { reduce foreign products } \\
\text { entry into Tanzania }\end{array}$ & 199 & 1 & 5 & 2.12 & 1.364 \\
\hline $\begin{array}{c}\text { 16. Buying products from } \\
\text { other countries puts } \\
\text { Tanzanians out of work }\end{array}$ & 200 & 1 & 5 & 2.73 & 1.440 \\
\hline
\end{tabular}




\section{Macrothink}

Research in Business and Management

ISSN 2330-8362

2020, Vol.7, No.2

Table 1.5 Correlations of consumer ethnocentrism items

\begin{tabular}{|c|c|c|c|c|c|c|c|c|c|c|c|c|c|c|c|c|}
\hline & CV 1 & CV 2 & CV 3 & CV 4 & CV 5 & CV 6 & CV 7 & CV 8 & CV 9 & $\begin{array}{c}\mathrm{CV} \\
10\end{array}$ & $\begin{array}{c}\mathrm{CV} \\
11\end{array}$ & $\begin{array}{l}\text { CV } \\
12\end{array}$ & $\begin{array}{l}\mathrm{CV} \\
13\end{array}$ & $\begin{array}{l}\mathrm{CV} \\
14\end{array}$ & $\begin{array}{l}\text { CV } \\
15\end{array}$ & $\begin{array}{l}\mathrm{CV} \\
16\end{array}$ \\
\hline CV1 & 1 & & & & & & & & & & & & & & & \\
\hline $\mathrm{CV} 2$ & $.496^{* *}$ & 1 & & & & & & & & & & & & & & \\
\hline CV3 & $.359^{* *}$ & $.351^{* *}$ & 1 & & & & & & & & & & & & & \\
\hline CV4 & $.201^{* *}$ & .036 & $.218^{* * *}$ & 1 & & & & & & & & & & & & \\
\hline CV5 & $.275^{* *}$ & $.221^{* *}$ & $.244^{* *}$ & $.393^{* *}$ & 1 & & & & & & & & & & & \\
\hline CV6 & $.241^{* *}$ & $.284^{* *}$ & $.275^{* *}$ & $.222^{* *}$ & $.527^{* *}$ & 1 & & & & & & & & & & \\
\hline CV7 & $.353^{* *}$ & $.268^{* * *}$ & $.305^{* *}$ & $.172^{*}$ & $.479^{* *}$ & $.431^{* *}$ & 1 & & & & & & & & & \\
\hline CV8 & $.237^{* *}$ & $.270^{* * *}$ & $.296^{* *}$ & .089 & .129 & $.187^{* *}$ & $.338^{* *}$ & 1 & & & & & & & & \\
\hline CV9 & $.308^{* *}$ & $.267^{* *}$ & $.303^{* *}$ & $.163^{*}$ & $.207^{* *}$ & $.207^{* *}$ & $.407^{* *}$ & $.367^{* *}$ & 1 & & & & & & & \\
\hline CV10 & $.237^{* * *}$ & $.262^{* *}$ & $.378^{* * *}$ & .014 & .101 & $.189^{* *}$ & $.357^{* *}$ & $.283^{* *}$ & $.407^{* *}$ & 1 & & & & & & \\
\hline CV11 & $.284^{* * *}$ & $.292^{* *}$ & $.255^{* *}$ & $.153^{*}$ & $.408^{* *}$ & $.461^{* *}$ & $.516^{* *}$ & $.304^{* *}$ & $.379^{* *}$ & $.323^{* *}$ & 1 & & & & & \\
\hline CV12 & $.386^{* *}$ & $.408^{* * *}$ & $.227^{* *}$ & .097 & $.237^{* *}$ & $.277^{* *}$ & $.548^{* *}$ & $.240^{* *}$ & $.272^{* *}$ & $.237^{* *}$ & $.413^{* *}$ & 1 & & & & \\
\hline CV13 & $.172^{*}$ & $.241^{* *}$ & $.271^{* *}$ & .112 & $.298^{* *}$ & $.305^{* *}$ & $.225^{* *}$ & $.179^{*}$ & $.298^{* *}$ & $.334^{* *}$ & $.337^{* *}$ & $.246^{* *}$ & 1 & & & \\
\hline CV14 & .139 & .059 & -.033 & $.371^{* *}$ & $.406^{* *}$ & $.382^{* *}$ & $.302^{* *}$ & .119 & .102 & .035 & $.398^{* *}$ & $.153^{*}$ & $.233^{* *}$ & 1 & & \\
\hline CV15 & $.325^{* *}$ & $.380^{* *}$ & $356^{* *}$ & .109 & $.255^{* *}$ & $.372^{* *}$ & $.352^{* *}$ & $.332^{* *}$ & $.297^{* *}$ & $.410^{* *}$ & $.413^{* *}$ & $.416^{* *}$ & $.338^{* *}$ & $.230^{* *}$ & 1 & \\
\hline CV16 & $.377^{* *}$ & $.274^{* *}$ & $.176^{*}$ & $.240^{* *}$ & $.457^{* *}$ & $.463^{* *}$ & $.494^{* *}$ & $.415^{* *}$ & $.290^{* *}$ & $.232^{* *}$ & $.494^{* *}$ & $.376^{* *}$ & $.353^{* *}$ & $.414^{* * *}$ & $.393^{* *}$ & 1 \\
\hline
\end{tabular}


Table 1.6 Total Variance Explained

\begin{tabular}{|c|c|c|c|c|c|c|}
\hline \multirow[b]{2}{*}{$\begin{array}{l}\text { Compone } \\
\text { nt }\end{array}$} & \multicolumn{3}{|c|}{ Initial Eigenvalues } & \multicolumn{3}{|c|}{$\begin{array}{c}\text { Rotation Sums of Squared } \\
\text { Loadings }\end{array}$} \\
\hline & Total & $\begin{array}{c}\% \text { of } \\
\text { Variance }\end{array}$ & $\begin{array}{c}\text { Cumulative } \\
\%\end{array}$ & Total & $\begin{array}{c}\% \text { of } \\
\text { Variance }\end{array}$ & $\begin{array}{c}\text { Cumulative } \\
\%\end{array}$ \\
\hline 1 & 5.362 & 33.514 & 33.514 & 2.995 & 18.721 & 18.721 \\
\hline 2 & 1.795 & 11.216 & 44.730 & 2.686 & 16.785 & 35.507 \\
\hline 3 & 1.073 & 6.704 & 51.434 & 2.323 & 14.516 & 50.022 \\
\hline 4 & 1.028 & 6.428 & 57.862 & 1.254 & 7.839 & 57.862 \\
\hline 5 & .921 & 5.755 & 63.617 & & & \\
\hline 6 & .833 & 5.204 & 68.822 & & & \\
\hline 7 & .767 & 4.794 & 73.615 & & & \\
\hline 8 & .673 & 4.204 & 77.819 & & & \\
\hline 9 & .629 & 3.930 & 81.749 & & & \\
\hline 10 & .528 & 3.302 & 85.051 & & & \\
\hline 11 & .500 & 3.122 & 88.173 & & & \\
\hline 12 & .456 & 2.851 & 91.024 & & & \\
\hline 13 & .412 & 2.578 & 93.602 & & & \\
\hline 14 & .401 & 2.507 & 96.109 & & & \\
\hline 15 & .337 & 2.106 & 98.215 & & & \\
\hline 16 & .286 & 1.785 & 100.000 & & & \\
\hline
\end{tabular}




\section{Macrothink $\Delta$ Institute ${ }^{\mathrm{m}}$}

Table 1.7 Rotated Component Matrix ${ }^{\mathrm{a}}$

\begin{tabular}{|c|c|c|c|c|}
\hline & \multicolumn{4}{|c|}{ Component } \\
\hline & 1 & 2 & 3 & 4 \\
\hline CV14 & .749 & & & \\
\hline CV16 & .692 & & & \\
\hline CV5 & .658 & & & .440 \\
\hline CV6 & .629 & & & \\
\hline CV11 & .607 & .430 & & \\
\hline CV7 & .547 & & .427 & \\
\hline CV10 & & .783 & & \\
\hline CV9 & & .625 & & \\
\hline CV13 & & .620 & & \\
\hline CV15 & & .552 & & \\
\hline CV3 & & .511 & .423 & .485 \\
\hline CV8 & & .478 & & \\
\hline CV1 & & & .775 & \\
\hline $\mathrm{CV} 2$ & & & .722 & \\
\hline CV12 & & & .630 & \\
\hline CV4 & & & & .742 \\
\hline \multicolumn{5}{|c|}{$\begin{array}{l}\text { Extraction Method: Principal Component Analysis. } \\
\text { Rotation Method: Varimax with Kaiser Normalization. }\end{array}$} \\
\hline \multicolumn{5}{|c|}{$\begin{array}{l}\text { a. Rotation converged in } 16 \text { iterations. * Values greater than } 0.40 \\
\text { were hold. }\end{array}$} \\
\hline
\end{tabular}


Table 1.8 Correlations of ethnocentrism and demographic factors

\begin{tabular}{|c|c|c|c|c|}
\hline & & Ethnocentrism & Gender & Age \\
\hline \multirow[t]{3}{*}{ Ethnocentrism } & Pearson Correlation & 1 & .100 & -.127 \\
\hline & Sig. (2-tailed) & & .172 & .082 \\
\hline & $\mathrm{N}$ & 189 & 189 & 189 \\
\hline \multirow[t]{3}{*}{ Gender } & Pearson Correlation & .100 & 1 & -.119 \\
\hline & Sig. (2-tailed) & .172 & & .092 \\
\hline & $\mathrm{N}$ & 189 & 200 & 200 \\
\hline \multirow[t]{3}{*}{ Age } & Pearson Correlation & -.127 & -.119 & 1 \\
\hline & Sig. (2-tailed) & .082 & .092 & \\
\hline & $\mathrm{N}$ & 189 & 200 & 200 \\
\hline
\end{tabular}

Table 1.9 Regression analysis

\begin{tabular}{|l|c|r|r|r|r|}
\hline Model & $\mathrm{R}$ & $\mathrm{R}$ Square & Adjusted R Square & Std. Error of the Estimate & Durbin-Watson \\
\hline 1 & $.153^{\mathrm{a}}$ & .024 & .013 & .99344722 & 1.500 \\
\hline
\end{tabular}

Table 1.10 ANOVA $^{\mathrm{a}}$

\begin{tabular}{|l|l|l|l|l|l|l|}
\hline \multicolumn{2}{|l|}{ Model } & $\begin{array}{l}\text { Sum of } \\
\text { Squares }\end{array}$ & df & $\begin{array}{l}\text { Mean } \\
\text { Square }\end{array}$ & F & Sig. \\
\hline \multirow{2}{*}{1} & $\begin{array}{l}\text { Regressio } \\
\mathrm{n}\end{array}$ & 4.430 & 2 & 2.215 & 2.244 & $.109^{\mathrm{b}}$ \\
\cline { 2 - 6 } & Residual & 183.570 & 186 & .987 & & \\
\cline { 2 - 6 } & Total & 188.000 & 188 & & & \\
\hline
\end{tabular}


Table 1.11 Coefficients ${ }^{\mathrm{a}}$

\begin{tabular}{|c|c|c|c|c|c|c|c|c|c|c|c|}
\hline \multirow{2}{*}{\multicolumn{2}{|c|}{ Model }} & \multicolumn{2}{|c|}{$\begin{array}{c}\text { Unstandardized } \\
\text { Coefficients }\end{array}$} & \multirow{2}{*}{\begin{tabular}{|c} 
Standardized \\
Coefficients
\end{tabular}} & \multirow[b]{2}{*}{$\mathrm{t}$} & \multirow[b]{2}{*}{ Sig. } & \multicolumn{3}{|c|}{ Correlations } & \multicolumn{2}{|c|}{$\begin{array}{c}\text { Collinearity } \\
\text { Statistics }\end{array}$} \\
\hline & & B & $\begin{array}{l}\text { Std. } \\
\text { Error }\end{array}$ & & & & Zero-order & Partial & Part & Tolerance & VIF \\
\hline \multirow[t]{3}{*}{1} & Constant) & .000 & .289 & & -.001 & .999 & & & & & \\
\hline & Age & -.138 & .086 & -.117 & $1.610^{-}$ & .109 & -.127 & -.117 & -.117 & .988 & 1.013 \\
\hline & Gender & .173 & .146 & .087 & 1.190 & .236 & .100 & .087 & .086 & .988 & 1.013 \\
\hline
\end{tabular}

a. Dependent Variable: Ethnocentrism

\section{Copyright Disclaimer}

Copyright reserved by the author(s).

This article is an open-access article distributed under the terms and conditions of the Creative Commons Attribution license (http://creativecommons.org/licenses/by/3.0/). 